\title{
Formulation of Orodispersible Tablets of Ondansetron HCl: Investigations Using Glycine-Chitosan Mixture as Superdisintegrant
}

\author{
Honey Goel, Nishant Vora, Ashok K. Tiwary, and Vikas Rana* \\ Pharmaceutics Division, Department of Pharmaceutical Sciences and Drug Research, \\ Punjabi University, Patiala, Punjab-147002, India
}

(Received May 29, 2008; Accepted January 5, 2009)

\begin{abstract}
The objective of this investigation was to prepare orodispersible tablets (ODTs) of ondansetron $\mathrm{HCl}$ using a direct compression method. A combination of glycine and chitosan was used as a disintegrating system and these tablets were compared for mechanical strength and disintegration time with those containing superdisintegrants. The Plackett-Burman screening design was used to screen the independent variables [concentration of glycine $\left(\mathrm{X}_{1}\right)$, concentration of chitosan $\left(\mathrm{X}_{2}\right)$, concentration of ondansetron $\mathrm{HCl}\left(\mathrm{X}_{3}\right)$ and tablet crushing strength $\left(\mathrm{X}_{4}\right)$ ] which were found to actively influence the dependent variables [disintegration time in the oral cavity (DT), wetting time (WT), and water absorption ratio (WAR)]. Further, a central composite design was used to formulate additional ODTs of ondansetron $\mathrm{HCl}$ for estimating response in the extended spherical domain. The regression analysis (performed using Statistica-7.0) of quadratic fit revealed that DT or WT and WAR were $99 \%$ and $98 \%$ correlated with active factors $\left(\mathrm{X}_{1}, \mathrm{X}_{2}\right.$ or $\left.\mathrm{X}_{3}\right)$, respectively. The data showed that disintegration time of optimized ondansetron HCl ODTs was not significantly different $(p<$ 0.05) from ODTs prepared using Croscarmellose sodium or Crospovidone.
\end{abstract}

Key words_— orodispersible tablet (ODT); glycine; chitosan; ondansetron $\mathrm{HCl}$; direct compression method

\section{INTRODUCTION}

Antiemetics are the agents which can block nausea and vomiting sensations, that are frequently encountered with chemotherapy, radiation therapy, during treatment of gastrointestinal tumors and in pregnancy. Persistent vomiting results in loss of hydrochloric acid, alkalosis and dehydration which in turn may precipitate further vomiting. Ondansetron $\mathrm{HCl}$ is a selective serotonin $5-\mathrm{HT}_{3}$ receptor antagonist indicated for the prevention of nausea and vomiting and reported to be well absorbed from the gastrointestinal tract. ${ }^{1)}$ Clinically, it is essential to administer ondansetron $\mathrm{HCl}$ with a minimum quantity of water in order to prevent subsequent episodes of vomiting due to the ingestion of water.

Recent advances in pharmaceutical research have been focused primarily on developing new and more patient compliant dosage forms. One such dosage form is an orodispersible tablet (ODT) .2) These are solid drug delivery systems that dissolve or disintegrate rapidly in the oral/buccal cavity, resulting in a solution or suspension without the need of water or chewing. ${ }^{3)}$

\footnotetext{
*e-mail: vikas_pbi@rediffmail.com
}

ODTs have many advantages such as rapid onset of action, improved bioavailability, ease of administration, useful for pediatric, geriatric and psychiatric patients, suitable during traveling where water may not be available, provide accurate dosing as compared to liquids and exhibit good chemical stability. ${ }^{4,5)}$ Although, the ODTs are advantageous, insufficient mechanical strength which in turn demands careful handling, restricts their use to a certain extent. Further, the ODTs may leave an unpleasant taste and grittiness in the mouth if not formulated properly.

Many approaches have been developed to manufacture ODTs. These include vacuum drying, ${ }^{6}$ lyophilization, molding and compressing wet powder to construct a highly porous structure, ${ }^{7)}$ crystalline transition method, ${ }^{8)}$ and direct compression method. ${ }^{9-11)}$ The direct compression method is inexpensive and convenient for producing tablets of sufficient mechanical integrity. Researchers are looking for directly compressible agents which can not only improve the mechanical integrity of ODTs but also disintegrate the tablets in a few seconds in the oral cavity. Superdisintegrants like croscarmellose sodium, crospovidone and sodium starch glycolate can quickly disintegrate only those tablets that possess 
tablet crushing strength less than $4 \mathrm{~kg} .{ }^{12)}$ Also, the addition of microcrystalline cellulose (Avicel-PH101 or PH102) or di-calcium phosphate while formulating ODTs to enhance disintegration causes an unpleasant feeling of grittiness in mouth.

Chitosan is a bio-polysaccharide derived from chitin, a polymer from bio-waste of the shell fish industry. Unionized chitosan is fibrous in nature and is reported to exhibit swelling in acidic media. ${ }^{13)}$ Chitosan, in its natural state, is reported to function as a good binder, thus enabling preparation of tablets with high crushing strength. Another property of swelling associated with chitosan can be envisaged to produce quick disintegration of tablets. Glycine has excellent wicking property ${ }^{14)}$ and can be expected to promote transport of water into the tablet very rapidly. Therefore, the combination of chitosan and glycine can be envisaged to produce tablets with high crushing strength capable of disintegrating very quickly.

In the light of these reports, the present work aimed at formulating ODTs of ondansetron $\mathrm{HCl}$ using a combination of glycine and chitosan as a sweet tasting disintegrating system by direct compression method. An attempt was made to optimize the disintegrating combination of glycine and chitosan for formulating ODTs of ondansetron $\mathrm{HCl}$ possessing comparable mechanical strength and lower DT than ODTs prepared using traditional superdisintegrants like crospovidone or croscarmellose sodium. The effect of concentration of chitosan and glycine on disintegration time (DT), wetting time (WT) and water absorption ratio (WAR) was evaluated to explore the mechanism of disintegration.

\section{EXPERIMENTAL}

Materials The gift samples of crospovidone and croscarmellose sodium (Panacea Biotech, Ltd., Lalru, India), and ondansetron $\mathrm{HCl}$ (99.9\%, IndSwift Labs., Parwano, India) were used as received. Chitosan powder (MW 70000, 90\% deacetylated, Indian Sea Foods, Cochin, India), glycine (Qualigens fine chemicals, Mumbai, India), spray dried lactose and potato starch ( $\mathrm{CDH}$, Mumbai, India) were used as supplied. All other reagents were of analytical grade.

\section{METHODS}

\section{Formulation of ODTs Using Unionized Chitosan}

The Plackett-Burman screening design was used to formulate ODTs to screen the effect of selected process and formulation variables on disintegration time (DT), wetting time (WT) and water absorption ratio (WAR). Additional ODTs were prepared according to a central composite design (CCD) using active variables (i.e., concentration of glycine $\left(\mathrm{X}_{1}\right)$, concentration of unionized chitosan $\left(\mathrm{X}_{2}\right)$ and tablet crushing strength $\left(\mathrm{X}_{4}\right)$ ) that were found to significantly influence the DT, WT and WAR during initial screening studies. The disintegration time of ODTs that were prepared using spray dried lactose, ondansetron $\mathrm{HCl}$ and croscarmellose sodium or crospovidone was compared with that obtained with a unionized chitosan-glycine mixture. Multiple linear regression was performed between active variables obtained from CCD and dependent variables and analyzed using Statistica ${ }^{\circledR}$-7.0 (Sta Soft Inc., Tulsa, USA). All the ODTs were prepared by the following method.

Glycine $(40-60 \% \mathrm{w} / \mathrm{w})$ and chitosan powder (5$10 \% \mathrm{w} / \mathrm{w})$ were mixed in a dry state. To this mixture, potato starch $(22-55 \% \mathrm{w} / \mathrm{w})$ and $(8 \% \mathrm{w} / \mathrm{w})$ ondansetron $\mathrm{HCl}$ were added and blended by tumbling. The resulting blend was compressed into tablets with a multipunch single station tableting machine (Cadmach, Ahmedabad, India). The average weight and diameter of ODT was $100 \pm 5 \mathrm{mg}$ and $6 \pm 0.5 \mathrm{~mm}$, respectively.

Formulation of Ondansetron HCl ODTs Using Superdisintegrants Crospovidone $(2.5-10 \% \mathrm{w} / \mathrm{w})$ or croscarmellose sodium $(2.5-10 \% \mathrm{w} / \mathrm{w}), 8 \% \mathrm{w} / \mathrm{w}$ of ondansetron $\mathrm{HCl}$ and spray dried lactose (81-88.5 $\% \mathrm{w} / \mathrm{w})$ were added and blended by tumbling. The resulting blend was compressed into tablets with a multipunch single station tableting machine (Cadmach, Ahmedabad, India). The average weight and diameter of ODT was $100 \pm 5 \mathrm{mg}$ and $6 \pm 0.5 \mathrm{~mm}$, respectively.

\section{Evaluation of ODTs}

Tablet Crushing Strength A Pfizer hardness tester was used to measure the tablet crushing strength. The data reported is the mean of six individual determinations.

Wetting Time (WT) Five circular pieces of tissue paper $(10 \mathrm{~cm}$ diameter) were placed in a Petri 
dish, and $10 \mathrm{ml}$ of $0.05 \%$ eosin dye solution in water was added to the dish. A tablet was carefully placed on the surface of the tissue paper. The time required for the dye solution to appear on the upper surface of the tablet was noted as wetting time. ${ }^{6}$

Water Absorption Ratio (WAR) A preweighed tablet was carefully placed on the surface of the tissue paper and the whole procedure discussed above was repeated using distilled water alone in place of the dye solution. After complete wetting, the tablet was weighed again and the water absorption ratio was calculated using the equation:

$$
W A R=\left(W_{\mathrm{b}}-W_{\mathrm{a}}\right) / W_{\mathrm{a}}
$$

where $W_{\mathrm{a}}$ and $W_{\mathrm{b}}$ are the weights of the tablet before and after water absorption, respectively.

\section{Weight Variation}

The weight variation test was performed on 20 randomly collected tablets from a batch of 100 . The procedure described in USP30NF25 was followed for this test. ${ }^{15)}$

Friability Tablets weighing $6.5 \mathrm{gm}$ were placed in a Roche friabilator. The friabilitor was operated at $25 \mathrm{rpm}$ for 4 minutes. The tablets were then reweighed after removal of fines (using 60 mesh screen) and the percentage weight loss was calculated. ${ }^{15}$ )

Content Uniformity For estimation of ondansetron $\mathrm{HCl}$ content in prepared tablets, 30 tablets were randomly selected from each batch and 10 were analyzed individually. ${ }^{15)}$ The amount of ondansetron $\mathrm{HCl}$ in ODTs was determined spectrophotometrically in $0.1 \mathrm{~N} \mathrm{HCl}$ by measuring the first derivative reading at $310 \mathrm{~nm}$ using a Beckman DU-640B UV/VIS spectrophotometer.

In Vivo Disintegration Time (DT) The in vivo DT was assessed in six healthy male volunteers for each batch of tablets. Complete disintegration of the tablets in the oral cavity was assessed according to the method described by Abdelbary et al.16) The volunteers were informed of the protocol and purpose of the study. According to the protocol, all the volunteers were asked to rinse their oral cavity with distilled water prior to the test. Each volunteer was asked to place one tablet on the tongue and a stopwatch was started immediately. The volunteers were given strict instructions not to chew or swallow the tablets, although licking was allowed. The end point of disintegration in the oral cavity was measured as the time when the tablet placed on the tongue disintegrated without leaving any lumps. All the volunteers were in- structed to rinse their mouth after completion of the test. The data reported is the mean $\pm \mathrm{SD}$ of six determinations.

In Vitro Release Studies Ondansetron $\mathrm{HCl}$ released from ODTs was evaluated using an USP dissolution apparatus II-paddle (Tab-Machines, Mumbai, India) at $37 \pm 0.5^{\circ} \mathrm{C}$ using $500 \mathrm{ml}$ of $0.1 \mathrm{~N} \mathrm{HCl}$ as dissolution media with a stirring speed of $50 \mathrm{rpm}$. Aliquots $(5 \mathrm{ml})$ withdrawn at different time intervals were immediately filtered through Whatmann filter paper $(11 \mu \mathrm{m})$ diluted suitably and analyzed for ondansetron $\mathrm{HCl}$ spectrophotometrically (Beckman DU 640B UV/VIS spectrophotometer, USA) at $310 \mathrm{~nm}$. The absorbance values were transformed to concentration by reference to a standard calibration curve obtained experimentally $\left(R^{2}=0.9998\right)$.

Similarity and Dissimilarity Factors A model independent approach was used to estimate the dissimilarity factor $\left(f_{1}\right)$ and similarity factor $\left(f_{2}\right)$ to compare the dissolution profile of ODTs containing the chitosan-glycine mixture with ODTs containing superdisintegrant. The FDA and SUPAC-IR guidelines define the difference factor $\left(f_{1}\right)$ as the calculated percent difference between the reference and test curve at each time point and is a measurement of the relative error between the two curves. The following equations were used for calculating $f_{1}$ and $f_{2}$.

$$
f_{1}=\left\{\left[\sum_{t=1}^{n}\left(R_{\mathrm{t}}-T_{\mathrm{t}}\right)\right] /\left[\sum_{t=1}^{n} R_{\mathrm{t}}\right]\right\} \times 100
$$

The similarity factor $\left(f_{2}\right)$ is given by the following equation:

$$
f_{2}=50 \times \log \left\{\left[1+1 / n \sum_{t=1}^{n}\left(R_{\mathrm{t}}-T_{\mathrm{t}}\right)^{2}\right]^{-0.5} \times 100\right\}
$$

where, $n$ is number of pull points, $R_{\mathrm{t}}$ is the reference batch profile at time ' $\mathrm{t}$ ' and $T_{\mathrm{t}}$ is the test batch profile at the same time point. For in vitro dissolution curves to be considered similar $f_{1}$ values should be in the range of $0-15$ while values of $f_{2}$ should lie within 50 100.11)

\section{RESULTS AND DISCUSSION}

Chitosan has a fibrous structure in the natural state and also, it exhibits excellent water sorbing properties. ${ }^{17)}$ Glycine is highly hygroscopic in nature, showed good wicking property ${ }^{14)}$ and has a pleasant and sweet taste. Therefore, the combination of chitosan and glycine is believed to offer a good biodegradable, non-toxic alternative to the existing synthetic superdisintegrants for formulating ODTs of drugs. 


\section{Screening of Active Process and Formulation Vari-}

ables The Plackett-Burman screening design was used to formulate ODTs for screening the process and formulation variables that produced a significant $(p$ $<0.05$ ) effect on DT, WT or WAR as shown in Table 1. The results obtained from significance test revealed that all these dependent variables were significantly influenced by concentration of glycine $\left(\mathrm{X}_{1}\right)$, concentration of chitosan $\left(\mathrm{X}_{2}\right)$ and tablet crushing strength $\left(\mathrm{X}_{4}\right)$. Further, the DT and WT of ODTs containing $60 \% \mathrm{w} / \mathrm{w}$ of glycine and $10 \% \mathrm{w} / \mathrm{w}$ of chitosan was less than ODTs containing $40 \% \mathrm{w} / \mathrm{w}$ of glycine and 5 $\% \mathrm{w} / \mathrm{w}$ of chitosan at all tablet crushing strengths examined. Moreover, WT was directly proportional to DT. This suggested wetting to be the only cause of disintegration of ODTs.

Mechanism of Disintegration The results of multiple linear regression revealed that the effect of various formulation and process variables $\left(\mathrm{X}_{1} \ldots \mathrm{X}_{7}\right)$ on DT $\left(\mathrm{Y}_{1}\right)$, WT $\left(\mathrm{Y}_{2}\right)$ and WAR $\left(\mathrm{Y}_{3}\right)$ could be represented by the equations:

$$
\begin{aligned}
& \mathrm{Y}_{1}=23.37-3.625 \mathrm{X}_{1}-3.125 \mathrm{X}_{2}-0.125 \mathrm{X}_{3}+4.125 \mathrm{X}_{4} \\
& +0.125 \mathrm{X}_{5}+0.125 \mathrm{X}_{6}-0.375 \mathrm{X}_{7} \\
& \mathrm{Y}_{2}=27-3.75 \mathrm{X}_{1}-3.5 \mathrm{X}_{2}-0.25 \mathrm{X}_{3}+4.5 \mathrm{X}_{4}+0.25 \mathrm{X}_{6} \\
& -0.25 \mathrm{X}_{7} \\
& \mathrm{Y}_{3}=1.962+0.175 \mathrm{X}_{1}+0.15 \mathrm{X}_{2}-0.025 \mathrm{X}_{3}-0.087 \mathrm{X}_{4} \\
& -0.025 \mathrm{X}_{5}-0.037 \mathrm{X}_{6}+0.0125 \mathrm{X}_{7}
\end{aligned}
$$

In the above equations, a negative sign signifies an antagonistic effect while a positive sign signifies a synergistic effect. Therefore, the equation generated after multiple linear regression revealed that increasing the concentration of glycine had an antagonistic effect and retarded the DT and WT. This seems to be due to the excellent wetting nature of glycine. ${ }^{14)}$ However, with decrease in glycine concentration, WAR decreased (Fig. 1). The DT and WT decreased with an increase in concentration of chitosan, whereas, the WAR increased with an increase in chitosan concentration. This could be attributed to the moisture sorption and water uptake properties of this bio-polysaccharide. ${ }^{17)}$ Therefore, an increase in concentration of chitosan increased the wicking property which led to the reduced DT and WT and an increase in WAR. Further, it was found that there was no increase in shape of any of the ODTs during disintegration. Therefore, it could be assumed that wetting was the only cause of disintegration. This indicated that aqueous medium penetrates into the tablet and replaces the air adsorbed on the particles, which weakens the intermolecular bonds and breaks the tablet into fine particles. Furthermore, the process variable, tablet crushing strength $\left(\mathrm{X}_{4}\right)$ had an opposite influence on

\begin{tabular}{|c|c|c|c|c|c|c|c|c|c|c|}
\hline $\begin{array}{c}\text { BATCH } \\
\text { NO. }\end{array}$ & $\begin{array}{c}\mathrm{X}_{1} \\
(\% \mathrm{w} / \mathrm{w})\end{array}$ & $\begin{array}{c}\mathrm{X}_{2} \\
(\% \mathrm{w} / \mathrm{w})\end{array}$ & $\begin{array}{c}\mathrm{X}_{3} \\
(\% \mathrm{w} / \mathrm{w})\end{array}$ & $\begin{array}{c}\mathrm{X}_{4} \\
(\mathrm{~kg})\end{array}$ & $\mathrm{X}_{5}$ & $\mathrm{X}_{6}$ & $\mathrm{X}_{7}$ & $\mathrm{Y}_{1}(\mathrm{~s})$ & $\mathrm{Y}_{2}(\mathrm{~s})$ & $\mathrm{Y}_{3}$ \\
\hline 1 & $+1(60 \%)$ & $+1(10 \%)$ & $+1(8 \%)$ & $-1(2.0)$ & +1 & -1 & -1 & $13 \pm 1$ & $15 \pm 1$ & $1.24 \pm 0.2$ \\
\hline 2 & $-1(40 \%)$ & $+1(10 \%)$ & $+1(8 \%)$ & $+1(4.0)$ & -1 & +1 & -1 & $29 \pm 3$ & $32 \pm 3$ & $1.85 \pm 0.2$ \\
\hline 3 & $-1(40 \%)$ & $-1(5 \%)$ & $+1(8 \%)$ & $+1(4.0)$ & +1 & -1 & +1 & $34 \pm 3$ & $38 \pm 3$ & $1.6 \pm 0.15$ \\
\hline 4 & $+1(60 \%)$ & $-1(5 \%)$ & $-1(4 \%)$ & $+1(4.0)$ & +1 & +1 & -1 & $28 \pm 2$ & $32 \pm 3$ & $1.8 \pm 0.2$ \\
\hline 5 & $-1(40 \%)$ & $+1(10 \%)$ & $-1(4 \%)$ & $-1(2.0)$ & +1 & +1 & +1 & $20 \pm 2$ & $23 \pm 2$ & $1.95 \pm 0.2$ \\
\hline 6 & $+1(60 \%)$ & $-1(5 \%)$ & $+1(4 \%)$ & $-1(2.0)$ & -1 & +1 & +1 & $19 \pm 2$ & $22 \pm 2$ & $2.1 \pm 0.3$ \\
\hline 7 & $+1(60 \%)$ & $+1(10 \%)$ & $-1(4 \%)$ & $+1(4.0)$ & -1 & -1 & +1 & $21 \pm 2$ & $24 \pm 2$ & $2.25 \pm 0.2$ \\
\hline 8 & $-1(40 \%)$ & $-1(5 \%)$ & $-1(4 \%)$ & $-1(2.0)$ & -1 & -1 & -1 & $27 \pm 2$ & $30 \pm 3$ & $1.75 \pm 0.2$ \\
\hline
\end{tabular}

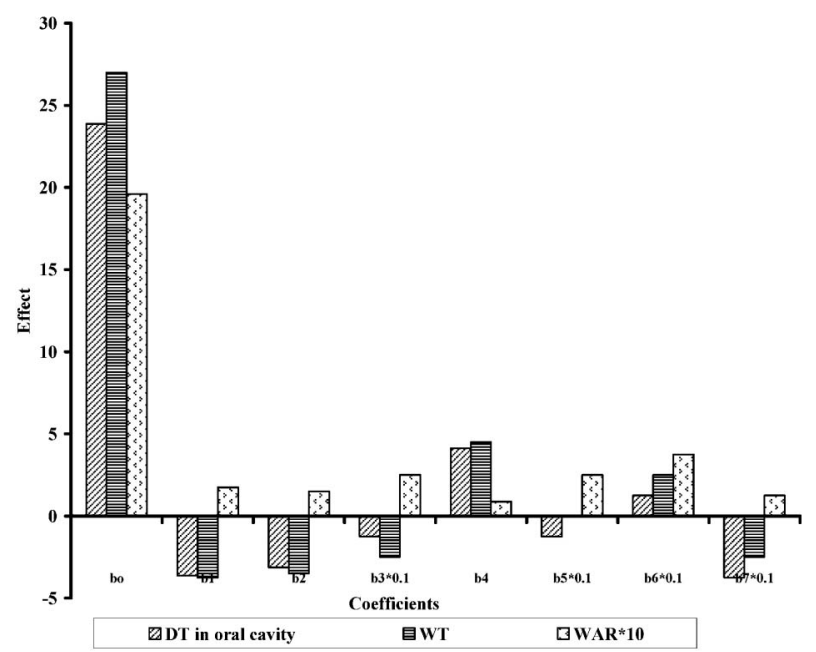

Fig. 1. The Coefficients Associated with the Effect of Various Formulations and Process Variables on DT in the Oral Cavity, WT and WAR of Ondansetron HCl ODTs

Table 1. Placket-Burman Screening Design for Identifying Active Formulation and Process Variables Influencing DT, WT or WAR

$\mathrm{X}_{1}=$ Concentration of glycine; $\mathrm{X}_{2}=$ Concentration of chitosan; $\mathrm{X}_{3}=$ Concentration of ondansetron $\mathrm{HCl} ; \mathrm{X}_{4}=$ Tablet crushing strength; $\mathrm{X}_{5}, \mathrm{X}_{6}$ and $\mathrm{X}_{7}$ are dummy variables; $\mathrm{Y}_{1}=\mathrm{DT}$ in oral cavity; $\mathrm{Y}_{2}=\mathrm{WT} ; \mathrm{Y}_{3}=\mathrm{WAR}$. 
dependent variables as compared to glycine and chitosan. The increase in tablet crushing strength increased the DT as well as WT and decreased the WAR. This suggests an overwhelming role of glycine, chitosan and tablet crushing strength in decreasing DT, WT and increasing WAR.

Effect of Ondansetron $\mathrm{HCl}$ on DT The concentration of ondansetron $\mathrm{HCl}$ was not found to be an active factor. However, increasing this concentration to more than $15 \% \mathrm{w} / \mathrm{w}$ increased the disintegration time to more than 50 seconds. Due to the high aqueous solubility of ondansetron $\mathrm{HCl},{ }^{18)}$ the water penetrating initially during the disintegration process rapidly produced a solution in the core of ODT. As a consequence, the penetration of additional water is expected to be obstructed due to the clogging of space by the dissolved ondansetron $\mathrm{HCl}$. This possibly led to delay in the disintegration of tablets. Therefore, all the ODTs were prepared using an adult dose of ondansetron $\mathrm{HCl}(8 \mathrm{mg})$ which amounts to $8 \% \mathrm{w} / \mathrm{w}$ of a tablet.

Screening of Interaction and Quadratic Terms

Central composite design (CCD) was used to estimate the extended effect of the active process and formulation variables $\left(\mathrm{X}_{1}, \mathrm{X}_{2}\right.$ and $\left.\mathrm{X}_{4}\right)$ on dependent variables $\left(\mathrm{Y}_{1}, \mathrm{Y}_{2}\right.$ or $\left.\mathrm{Y}_{3}\right)$ in an extended spherical domain. Therefore, additional ODTs were prepared using extrapolated levels of the active process and formulation variables according to $\mathrm{CCD}$ as given in $\mathrm{Ta}$ ble 2 .

A statistical model incorporating interactive and polynomial terms was used to evaluate the responses obtained from CCD,

$\mathrm{Y}=\mathrm{b}_{0}+\mathrm{b}_{1} \mathrm{X}_{1}+\mathrm{b}_{2} \mathrm{X}_{2}+\mathrm{b}_{3} \mathrm{X}_{3}+\mathrm{b}_{12} \mathrm{X}_{1} \mathrm{X}_{2}+\mathrm{b}_{13} \mathrm{X}_{1} \mathrm{X}_{3}+\mathrm{b}_{23}$ $\mathrm{X}_{2} \mathrm{X}_{3}+\mathrm{b}_{11} \mathrm{X}_{1}^{2}+\mathrm{b}_{22} \mathrm{X}_{2}^{2}+\mathrm{b}_{33} \mathrm{X}_{3}^{2}$

where $\mathrm{Y}$ represents the selected response, $\mathrm{b}_{0}$ is the arithmetic mean of individual response and $b_{i}$ is the estimated coefficient for the factor $\mathrm{X}_{\mathrm{i}}$. Further, the values of the coefficients relate to the respective effect on DT $\left(\mathrm{Y}_{1}\right)$, WT $\left(\mathrm{Y}_{2}\right)$ and WAR $\left(\mathrm{Y}_{3}\right)$.

Table 3 summarizes the coefficients associated with active variables. The main effects $\left(\mathrm{X}_{1}, \mathrm{X}_{2}\right.$ and $\left.\mathrm{X}_{4}\right)$ represent the average result of changing one factor at a time from its low to high value. The interaction terms $\left(\mathrm{X}_{1} \mathrm{X}_{2}, \mathrm{X}_{1} \mathrm{X}_{4}, \mathrm{X}_{2} \mathrm{X}_{4}\right.$ and $\left.\mathrm{X}_{1} \mathrm{X}_{2} \mathrm{X}_{4}\right)$ show the variation in response when two or three factors were simultaneously changed. The second order quadratic terms $\left(\mathrm{X}_{1}^{2}, \mathrm{X}_{2}^{2}\right.$ and $\left.\mathrm{X}_{4}^{2}\right)$ are included to investigate non linearity. Also, a negative sign indicates an antagonistic effect while a positive sign indicates a synergistic

Table 2. Central Composite Design Using Active Formulation and Process Variables Influencing DT $\left(\mathrm{Y}_{1}\right)$, WT $\left(\mathrm{Y}_{2}\right)$ and WAR $\left(\mathrm{Y}_{3}\right)$

\begin{tabular}{ccccccc}
\hline \hline $\begin{array}{c}\text { Exp } \\
\text { no. }\end{array}$ & $\begin{array}{c}\mathrm{X}_{1} \\
(\% \mathrm{w} / \mathrm{w})\end{array}$ & $\begin{array}{c}\mathrm{X}_{2} \\
(\% \mathrm{w} / \mathrm{w})\end{array}$ & $\begin{array}{c}\mathrm{X}_{4} \\
(\mathrm{~kg})\end{array}$ & $\begin{array}{c}\mathrm{Y}_{1} \\
(\mathrm{~s})\end{array}$ & $\begin{array}{c}\mathrm{Y}_{2} \\
(\mathrm{~s})\end{array}$ & $\begin{array}{c}\mathrm{Y}_{3} \\
(\%)\end{array}$ \\
\hline $1 \mathrm{~F}$ & -1 & -1 & -1 & $27 \pm 2$ & $30 \pm 3$ & $1.75 \pm 0.2$ \\
$2 \mathrm{~F}$ & 1 & -1 & -1 & $19 \pm 1$ & $22 \pm 2$ & $2.1 \pm 0.2$ \\
$3 \mathrm{~F}$ & -1 & 1 & -1 & $20 \pm 2$ & $23 \pm 2$ & $1.95 \pm 0.2$ \\
$4 \mathrm{~F}$ & 1 & 1 & -1 & $13 \pm 1$ & $15 \pm 1$ & $2.4 \pm 0.25$ \\
$5 \mathrm{~F}$ & -1 & -1 & 1 & $34 \pm 3$ & $38 \pm 3$ & $1.6 \pm 0.15$ \\
$6 \mathrm{~F}$ & 1 & -1 & 1 & $28 \pm 2$ & $32 \pm 3$ & $1.8 \pm 0.2$ \\
$7 \mathrm{~F}$ & -1 & 1 & 1 & $29 \pm 3$ & $32 \pm 3$ & $1.85 \pm 0.2$ \\
$8 \mathrm{~F}$ & 1 & 1 & 1 & $21 \pm 2$ & $24 \pm 2$ & $2.25 \pm 0.2$ \\
$1 \mathrm{~S}$ & -1.682 & 0 & 0 & $31 \pm 3$ & $35 \pm 3$ & $1.6 \pm 0.15$ \\
$2 \mathrm{~S}$ & 1.682 & 0 & 0 & $18 \pm 2$ & $21 \pm 2$ & $2.45 \pm 0.4$ \\
$3 \mathrm{~S}$ & 0 & -1.682 & 0 & $29 \pm 3$ & $32 \pm 3$ & $1.8 \pm 0.2$ \\
$4 \mathrm{~S}$ & 0 & 1.682 & 0 & $19 \pm 2$ & $22 \pm 2$ & $2.25 \pm 0.3$ \\
$5 \mathrm{~S}$ & 0 & 0 & -1.682 & $18 \pm 2$ & $21 \pm 2$ & $2.15 \pm 0.25$ \\
$6 \mathrm{~S}$ & 0 & 0 & 1.682 & $31 \pm 3$ & $35 \pm 3$ & $1.9 \pm 0.2$ \\
$1 \mathrm{C}$ & 0 & 0 & 0 & $23 \pm 2$ & $26 \pm 2$ & $2 \pm 0.3$ \\
$2 \mathrm{C}$ & 0 & 0 & 0 & $23 \pm 2$ & $26 \pm 2$ & $2 \pm 0.25$ \\
$3 \mathrm{C}$ & 0 & 0 & 0 & $23 \pm 2$ & $26 \pm 2$ & $2 \pm 0.3$ \\
$4 \mathrm{C}$ & 0 & 0 & 0 & $23 \pm 2$ & $26 \pm 2$ & $2 \pm 0.3$ \\
\hline
\end{tabular}

$\mathrm{X}_{1}=$ Concentration of glycine; $\mathrm{X}_{2}=$ Concentration of chitosan; $\mathrm{X}_{4}=$ Tablet crushing strength; $\mathrm{F}$ : Factorial Design; S: Star Design; C: Center Points; values represent mean \pm SD $(n=6)$. 
Table 3. Quadratic Model and the Coefficients for DT in Oral Cavity, WT and WAR

\begin{tabular}{|c|c|c|c|c|c|c|c|c|c|c|c|c|}
\hline \multirow{2}{*}{$\begin{array}{c}\begin{array}{c}R^{2} \rightarrow \\
\text { Regression } \\
\text { coefficients }\end{array} \\
\text { Term }\end{array}$} & \multicolumn{4}{|c|}{$\begin{array}{c}\text { DT (s) } \\
99 \%\end{array}$} & \multicolumn{4}{|c|}{$\begin{array}{c}\text { WT (s) } \\
99 \%\end{array}$} & \multicolumn{4}{|c|}{$\begin{array}{c}\text { WAR (\%) } \\
98 \%\end{array}$} \\
\hline & $\mathrm{CF}$ & SE & $*_{t_{\text {table }}}^{\mathrm{SE} \times}=\mathrm{C}$ & ${ }^{\mathrm{a}} \mathrm{sig}$ & $\mathrm{CF}$ & SE & ${ }_{t_{\text {table }}}^{\mathrm{Sb} \times}=\mathrm{C}$ & ${ }^{\mathrm{a}} \mathrm{sig}$ & $\mathrm{CF}$ & $\mathrm{SE}$ & ${ }^{\stackrel{S}{\mathrm{SE}} \times} \underset{\mathrm{t} \text { table }}{=}=\mathrm{C}$ & ${ }^{\mathrm{a}}$ sig \\
\hline $\mathrm{b}_{0}$ & 22.33 & 0.618 & 1.3 & S & 25 & 0.83 & 1.73 & S & 1.890 & 0.06 & 0.13 & $\mathrm{~S}$ \\
\hline $\mathrm{b}_{1}$ & -3.72 & 0.16 & 0.34 & S & -3.92 & 0.22 & 0.46 & S & 0.270 & 0.016 & 0.034 & $\mathrm{~S}$ \\
\hline $\mathrm{b}_{2}$ & -3.06 & 0.16 & 0.34 & S & -3.28 & 0.22 & 0.46 & S & 0.143 & 0.016 & 0.034 & S \\
\hline $\mathrm{b}_{4}$ & 4.01 & 0.16 & 0.34 & S & 4.36 & 0.22 & 0.46 & S & -0.082 & 0.016 & 0.034 & S \\
\hline$b_{1} b_{2}$ & -0.125 & 0.21 & 0.45 & NS & -0.25 & 0.28 & 0.60 & NS & 0.037 & 0.021 & 0.044 & NS \\
\hline$b_{1} b_{4}$ & 0.125 & 0.21 & 0.45 & NS & 0.25 & 0.28 & 0.60 & NS & -0.025 & 0.021 & 0.044 & NS \\
\hline$b_{2} b_{4}$ & 0.125 & 0.21 & 0.45 & NS & 0 & 0.28 & 0.60 & NS & 0.025 & 0.021 & 0.044 & NS \\
\hline$b_{1} b_{2} b_{4}$ & -0.375 & 0.21 & 0.45 & NS & -0.25 & 0.28 & 0.60 & NS & 0.0125 & 0.021 & 0.044 & NS \\
\hline $\mathrm{b}_{1}{ }^{2}$ & 0.51 & 0.25 & 0.54 & NS & 0.74 & 0.34 & 0.71 & NS & 0.028 & 0.025 & 0.053 & NS \\
\hline $\mathrm{b}_{2}{ }^{2}$ & 0.23 & 0.25 & 0.54 & NS & 0.81 & 0.34 & 0.71 & NS & 0.028 & 0.025 & 0.053 & NS \\
\hline $\mathrm{b}_{4}{ }^{2}$ & 0.51 & 0.25 & 0.54 & NS & 0.74 & 0.34 & 0.71 & NS & 0.028 & 0.025 & 0.053 & NS \\
\hline
\end{tabular}

The ${ }^{*} t_{\text {table }}$ value for 18 degree of freedom and $95 \%$ level confidence is 2.1 . asig = significance; $\mathrm{S}=$ significant difference (If $\mathrm{CF}>\mathrm{C}$ ) ; NS $=$ no significant difference (If $\mathrm{CF}<\mathrm{C}$ ) $\mathrm{CF}=$ coefficients and $\mathrm{SE}=$ standard error.

Table 4. Reduced Model Equations for DT in Oral Cavity $\left(\mathrm{Y}_{1}\right)$, WT $\left(\mathrm{Y}_{2}\right)$ and WAR $\left(\mathrm{Y}_{3}\right)$

\begin{tabular}{cccc}
\hline \hline \multirow{2}{*}{ Treatment } & \multicolumn{3}{c}{ Equations correlating dependent variables with active factors } \\
& $\mathrm{DT}\left(\mathrm{Y}_{1}\right)$ & $\mathrm{WT}\left(\mathrm{Y}_{2}\right)$ & WAR $\left(\mathrm{Y}_{3}\right)$ \\
\hline $\mathrm{X}_{1} v / s \mathrm{X}_{2}$ & $\mathrm{Y}_{1}=24.02-3.72 \mathrm{X}_{1}-3.06 \mathrm{X}_{2}$ & $\mathrm{Y}_{2}=27.03-3.92 \mathrm{X}_{1}+3.28 \mathrm{X}_{2}$ & $\mathrm{Y}_{3}=2.0+0.21 \mathrm{X}_{1}+0.143 \mathrm{X}_{2}$ \\
$\mathrm{X}_{1} v / s \mathrm{X}_{4}$ & $\mathrm{Y}_{1}=24.02-3.72 \mathrm{X}_{1}+4.01 \mathrm{X}_{4}$ & $\mathrm{Y}_{2}=27.03-3.92 \mathrm{X}_{1}+4.36 \mathrm{X}_{4}$ & $\mathrm{Y}_{3}=2.0+0.21 \mathrm{X}_{1}-0.094 \mathrm{X}_{4}$ \\
$\mathrm{X}_{2} v / s \mathrm{X}_{4}$ & $\mathrm{Y}_{1}=24.02-3.06 \mathrm{X}_{2}+4.01 \mathrm{X}_{4}$ & $\mathrm{Y}_{2}=27.03-3.28 \mathrm{X}_{2}+4.36 \mathrm{X}_{4}$ & $\mathrm{Y}_{3}=2.0+0.143 \mathrm{X}_{2}-0.094 \mathrm{X}_{4}$ \\
\hline
\end{tabular}

effect.

The regression statistics of the quadratic model revealed that DT in the oral cavity or WT and WAR were $99 \%$ and $98 \%$ correlated with factors $\left(\mathrm{X}_{1}, \mathrm{X}_{2}\right.$ and $\mathrm{X}_{4}$ ), respectively. However, the interaction terms and second order quadratic terms revealed no significant influence $(p<0.05)$ on DT in any of the three factors. Therefore, a reduced model was generated by omitting interactions and quadratic terms. The reduced equations were generated by utilizing coefficients of active variables and responses (DT, WT and WAR) as shown in Table 4.

Optimization of ODTs Croscarmellose sodium and crospovidone are well known superdisintegrants used in ODTs. They have excellent disintegrating ability. Croscarmellose sodium swells to a large extent when it comes in contact with water. Also, it has a fibrous nature that allows intraparticulate as well as extraparticulate wicking of water even at a low concentration level.9) Crospovidone has an excellent wicking nature though it swells only minimally. ${ }^{19)}$ The ODTs containing croscarmellose sodium or crospovidone generally disintegrated within $30 \mathrm{~s}$ at a tablet crushing strength of $3 \mathrm{~kg}$. However, at a strength of more than $3 \mathrm{~kg}$, the DT of tablets is reported to be more than 60 s. ${ }^{12)}$ Hence, the maximum value of tablet crushing strength of ODTs prepared using croscarmellose sodium or crospovidone was fixed at $3 \mathrm{~kg}$. On this basis, ODTs of ondansetron $\mathrm{HCl}$ were prepared by direct compression method utilizing various concentrations of croscarmellose sodium or crospovidone as summarized in Table 5. The disintegration time of ODTs containing croscarmellose sodium $\left(\mathrm{CS}_{1}-\mathrm{CS}_{4}\right)$ or crospovidone $\left(\mathrm{CP}_{1}-\mathrm{CP}_{4}\right)$ was observed to decrease with an increase in their respective concentrations.

Hence, the batches $\mathrm{CS}_{3}, \mathrm{CS}_{4}, \mathrm{CP}_{3}$ and $\mathrm{CP}_{4}$ were selected for further study as they showed minimum disintegration time. DT in oral cavity $\left(\mathrm{Y}_{1}\right)$ was selected as a dependent variable and different formulations were prepared for optimizing the concentration of glycine and chitosan. The reduced model equation generated from correlation of $\mathrm{Y}_{1}$ and three active variables of CCD as in Table 4 were solved to calculate optimum values of $\mathrm{X}_{1}$ (concentration of glycine), 
$\mathrm{X}_{2}$ (concentration of chitosan) and $\mathrm{X}_{4}$ (tablet crushing strength). For this purpose an addition or subtraction method was used to obtain the optimized values of $\mathrm{X}_{1}, \mathrm{X}_{2}$ and $\mathrm{X}_{4}$ in terms of $\mathrm{Y}_{1}$ and constant terms in the equation. The disintegration time of ODTs obtained from various formulations $\left(\mathrm{CS}_{3}\right.$, $\mathrm{CS}_{4}, \mathrm{CP}_{3}$ and $\mathrm{CP}_{4}$ ) shown in Table 5 was then substituted in place of $Y_{1}$ to obtain respective calculated optimized values of $\mathrm{X}_{1}, \mathrm{X}_{2}$ and $\mathrm{X}_{4}$. These calculated optimized values were used for preparing ODTs containing glycine, chitosan and ondansetron $\mathrm{HCl}$ that would exhibit disintegration time comparable to the disintegration time of ODTs prepared using crospovidone or croscarmellose sodium as given in Table 6 . The optimized variables $\mathrm{X}_{1}, \mathrm{X}_{2}$ and $\mathrm{X}_{4}$ generated for preparing ondansetron $\mathrm{HCl}$ ODTs indicated that all these tablets were prepared at higher tablet crushing strengths than ODTs containing croscarmellose sodium or crospovidone. Also, it is evident from Table 6 that ondansetron $\mathrm{HCl}$ ODTs prepared using the optimized values of active variables $\left(\mathrm{B}_{1}-\mathrm{B}_{4}\right)$ exhibited lower disintegration time in the oral cavity than ODTs containing croscarmellose sodium or crospovidone
$\left(\mathrm{CS}_{3}, \mathrm{CS}_{4}, \mathrm{CP}_{3}\right.$ and $\left.\mathrm{CP}_{4}\right)$

\section{Evaluation of Optimized ODTs: A Comparison} with Superdisintegrants A comparison of optimized ODTs (B) with those containing croscarmellose sodium (CS) or crospovidone (CP) revealed that the percentage friability of optimized ODTs was significantly $(p<0.05)$ lower, than ODTs containing superdisintegrants as shown in Table 7. However, no statistical difference $(p<0.05)$ was obtained with respect to weight variation, drug content or average weight of tablets. The angle of repose of the granules of optimized batch $\left(\mathrm{B}_{1}\right)$ was found to be $24.2^{\circ} \pm$ $1.98^{\circ}$. This indicated excellent flowability of the glycine-chitosan-ondansetron $\mathrm{HCl}$ mixture. Interestingly, the DT of the optimized ODTs that were compressed to higher crushing strength was similar to the DT of ODTs containing croscarmellose sodium or crospovidone compressed at crushing strength of less than $3 \mathrm{~kg}$. Therefore, the best batch $\mathrm{B}_{1}$ of optimized ODTs was selected for further evaluation as it was compressed at the highest tablet crushing strength of $4.5 \mathrm{~kg}$. Figure 2 shows the effect of crushing strength on DT and on WT of ODTs prepared using croscar-

Table 5. Formulation Ondansetron $\mathrm{HCl}$ ODTs Containing Croscarmellose Sodium (CS) and Crospovidone (CP)

\begin{tabular}{lcccccccc}
\hline \multicolumn{1}{c}{ Formulation no. } & $\mathrm{CP}_{1}$ & $\mathrm{CP}_{2}$ & $\mathrm{CP}_{3}$ & $\mathrm{CP}_{4}$ & $\mathrm{CS}_{1}$ & $\mathrm{CS}_{2}$ & $\mathrm{CS}_{3}$ & $\mathrm{CS}_{4}$ \\
\hline Spray dried lactose (mg) & 88.5 & 86.0 & 83.5 & 81.0 & 88.5 & 86.0 & 83.5 & 81.0 \\
Croscarmellose sodium (mg) & - & - & - & - & 2.5 & 5 & 7.5 & 10 \\
Crospovidone (mg) & 2.5 & 5 & 7.5 & 10 & - & - & - & - \\
Ondansetron HCl (mg) & 8 & 8 & 8 & 8 & 8 & 8 & 8 & 8 \\
Colloidal silica (mg) & 1 & 1 & 1 & 1 & 1 & 1 & 1 & 1 \\
Total weight (mg) & 100 & 100 & 100 & 100 & 100 & 100 & 100 & 100 \\
Tablet crushing strength (kg) & 3.0 & 3.0 & 3.0 & 3.0 & 3.0 & 3.0 & 3.0 & 3.0 \\
$*$ DT in oral cavity (s) & $47 \pm 4$ & $37 \pm 3$ & $31 \pm 3$ & $29 \pm 2$ & $51 \pm 4$ & $42 \pm 3$ & $36 \pm 3$ & $32 \pm 2$ \\
\hline
\end{tabular}

* Data represents mean \pm SD $(n=6)$.

Table 6. Optimized Compositions of ODTs of Ondansetron $\mathrm{HCl}$ and Comparison of DT in Oral Cavity with Tablets Containing Croscarmellose Sodium or Crospovidone

\begin{tabular}{|c|c|c|c|c|c|c|c|}
\hline \multicolumn{2}{|c|}{$\begin{array}{l}\text { Tablets containing super } \\
\text { disintegrants }\end{array}$} & \multicolumn{5}{|c|}{ Solved values and optimized tablet composition } & \multirow{3}{*}{$\begin{array}{l}\text { Statistical difference } \\
\text { between A and B }\end{array}$} \\
\hline \multirow{2}{*}{$\begin{array}{l}\text { Formulation } \\
\text { Number }\end{array}$} & \multirow{2}{*}{$\begin{array}{c}\mathrm{DT}(\mathrm{s}) \\
\left(\mathrm{Y}_{1}\right) \\
\mathrm{A}^{*}\end{array}$} & \multirow{2}{*}{$\begin{array}{c}\text { Formulation } \\
\text { number }\end{array}$} & \multicolumn{3}{|c|}{ Optimized variables } & \multirow{2}{*}{$\begin{array}{l}\text { DT of optimized tablets } \\
\text { containing glycine- } \\
\text { chitosan-starch mixture B* }\end{array}$} & \\
\hline & & & $\begin{array}{c}\mathrm{X}_{1} \\
(\% \mathrm{w} / \mathrm{w})\end{array}$ & $\begin{array}{c}\mathrm{X}_{2} \\
(\% \mathrm{w} / \mathrm{w})\end{array}$ & $\begin{array}{c}\mathrm{X}_{4} \\
(\mathrm{~kg})\end{array}$ & & \\
\hline $\mathrm{CS}_{3}$ & $36 \pm 2$ & $\mathrm{~B}_{1}$ & 34 & 2.6 & 4.5 & $38 \pm 3$ & NS \\
\hline $\mathrm{CS}_{4}$ & $32 \pm 2$ & $\mathrm{~B}_{2}$ & 39.5 & 4.2 & 4 & $33 \pm 3$ & NS \\
\hline $\mathrm{CP}_{3}$ & $31 \pm 2$ & $\mathrm{~B}_{3}$ & 40.6 & 4.7 & 3.9 & $32 \pm 2$ & NS \\
\hline $\mathrm{CP}_{4}$ & $29 \pm 2$ & $\mathrm{~B}_{4}$ & 43.3 & 5.5 & 3.6 & $29 \pm 2$ & NS \\
\hline
\end{tabular}

\footnotetext{
* Data represent mean $\pm \mathrm{SD}(n=6)$.
} 
Table 7. Comparison of Optimized ODTs $\left(\mathrm{B}_{1}-\mathrm{B}_{4}\right)$ with ODTs Containing Croscarmellose Sodium or Crospovidone

\begin{tabular}{|c|c|c|c|c|c|c|c|c|c|c|c|c|}
\hline $\begin{array}{c}\text { Formulation no. } \rightarrow \\
\text { Tablet properties } \\
\downarrow\end{array}$ & $\mathrm{CS}_{3}$ & $\mathrm{~B}_{1}$ & *Sig & $\mathrm{CS}_{4}$ & $\mathrm{~B}_{2}$ & Sig & $\mathrm{CP}_{3}$ & $\mathrm{~B}_{3}$ & Sig & $\mathrm{CP}_{4}$ & $\mathrm{~B}_{4}$ & Sig \\
\hline $\begin{array}{l}\text { Weight variation } \\
(\%) \pm \text { SD }\end{array}$ & $\begin{array}{r}2.92 \pm \\
0.02\end{array}$ & $\begin{array}{c}2.91 \pm \\
0.03\end{array}$ & NS & $\begin{array}{r}2.58 \pm \\
0.03\end{array}$ & $\begin{array}{r}2.47 \pm \\
0.08\end{array}$ & NS & $\begin{array}{r}2.61 \pm \\
0.09\end{array}$ & $\begin{array}{r}2.32 \pm \\
0.02\end{array}$ & NS & $\begin{array}{r}1.48 \pm \\
0.06\end{array}$ & $\begin{array}{r}1.54 \pm \\
0.08\end{array}$ & NS \\
\hline $\begin{array}{l}\text { Drug content } \\
(\%) \pm \mathrm{SD}(\%)\end{array}$ & $\begin{array}{r}98.9 \pm \\
0.04\end{array}$ & $\begin{array}{c}99.5 \pm \\
0.08\end{array}$ & NS & $\begin{array}{r}99.6 \pm \\
0.07\end{array}$ & $\begin{array}{r}99.4 \pm \\
0.04\end{array}$ & NS & $\begin{array}{r}98.8 \pm \\
0.06\end{array}$ & $\begin{array}{r}99.3 \pm \\
0.06\end{array}$ & NS & $\begin{array}{r}99.6 \pm \\
0.08\end{array}$ & $\begin{array}{c}99.5 \pm \\
0.02\end{array}$ & NS \\
\hline $\begin{array}{l}\% \text { Friability } \\
\pm \text { SD (\%) }\end{array}$ & $\begin{array}{r}1.18 \pm \\
0.01\end{array}$ & $\begin{array}{r}0.63 \pm \\
0.01\end{array}$ & $\mathrm{~S}$ & $\begin{array}{r}0.88 \pm \\
0.03\end{array}$ & $\begin{array}{r}0.47 \pm \\
0.02\end{array}$ & $\mathrm{~S}$ & $\begin{array}{r}0.98 \pm \\
0.01\end{array}$ & $\begin{array}{r}0.52 \pm \\
0.01\end{array}$ & $\mathrm{~S}$ & $\begin{array}{r}0.89 \pm \\
0.02\end{array}$ & $\begin{array}{r}0.42 \pm \\
0.02\end{array}$ & $\mathrm{~S}$ \\
\hline $\begin{array}{l}\text { Average weight } \\
\text { (mg) of } 20 \text { tablets }\end{array}$ & $\begin{array}{r}98.6 \pm \\
1.36\end{array}$ & $\begin{array}{c}99.5 \pm \\
1.58\end{array}$ & NS & $\begin{array}{r}98.4 \pm \\
1.46\end{array}$ & $\begin{array}{r}98.3 \pm \\
1.58\end{array}$ & NS & $\begin{array}{r}98.6 \pm \\
1.39\end{array}$ & $\begin{array}{r}99.4 \pm \\
1.45\end{array}$ & NS & $\begin{array}{r}98.0 \pm \\
1.25\end{array}$ & $\begin{array}{l}99.0 \pm \\
0.23\end{array}$ & NS \\
\hline Batch size（tablets） & 100 & 100 & & 100 & 100 & & 100 & 100 & & 100 & 100 & \\
\hline
\end{tabular}

* Sig=significance; $\mathrm{NS}=$ no significant difference; $\mathrm{S}=$ significant difference, data given is mean $\pm \mathrm{SD}(n=6)$.

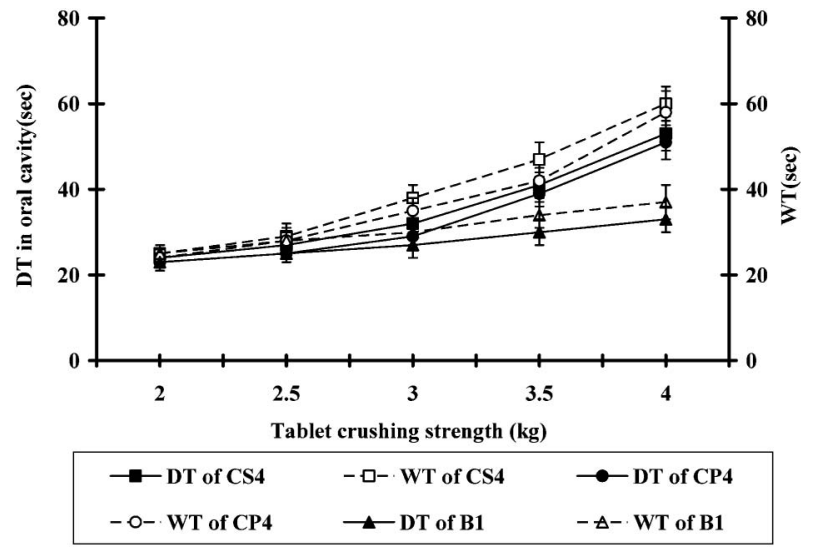

Fig. 2. Relationship between DT in the Oral Cavity and WT with Tablet Crushing Strength of Optimized ODTs $\left(\mathrm{B}_{1}\right)$ and ODTs Prepared Using Croscarmellose Sodium $\left(\mathrm{CS}_{4}\right)$ and crospovidone $\left(\mathrm{CP}_{4}\right)$

mellose sodium $\left(\mathrm{CS}_{4}\right)$, crospovidone $\left(\mathrm{CP}_{4}\right)$ and optimized ODTs $\left(\mathrm{B}_{1}\right)$. A comparison of the tablets prepared with glycine-chitosan with those prepared using superdisintegrants revealed a nonlinear relationship between DT in the oral cavity and tablet crushing strength and also between WT and tablet crushing strength (Fig. 2). However, a linear relationship was observed between DT in the oral cavity and tablet crushing strength of $\mathrm{B}_{1}$ ODT batches. A linear relationship was also seen between WT and tablet crushing strength of $\mathrm{B}_{1}$ ODT batches. Further, DT in the oral cavity and WT followed the order: $\mathrm{CS}_{4}>\mathrm{CP}_{4}$ $>\mathrm{B}_{1}$ at more than $3 \mathrm{~kg}$ crushing strength. This indicated that the $B_{1}$ batch possessed the most rapid wetting as well as disintegration property in the oral cavity even at a tablet crushing strength of more than 3 kg. On the other hand, $\mathrm{CS}_{4}$ and $\mathrm{CP}_{4}$ batches did not exhibit this property.

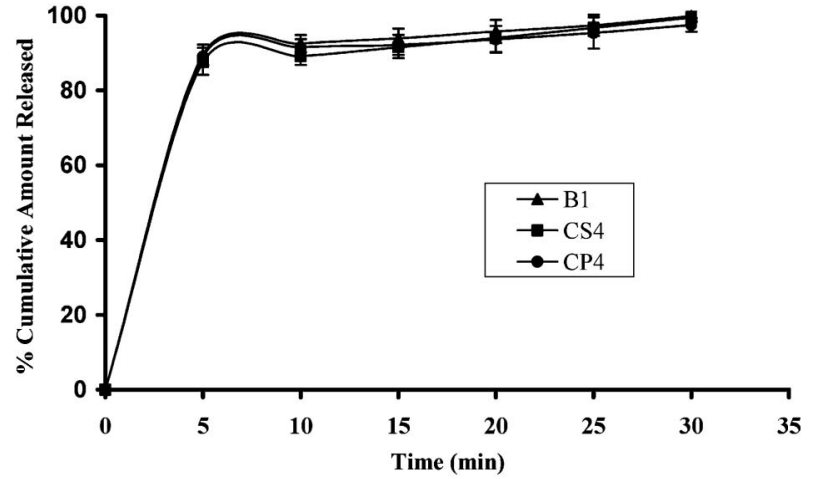

Fig. 3. In Vitro Ondansetron $\mathrm{HCl}$ Release from ODTs of Batches $\mathrm{B}_{1}, \mathrm{CS}_{4}$ and $\mathrm{CP}_{4}$

The release of ondansetron $\mathrm{HCl}$ from tablets of $\mathrm{CS}_{4}, \mathrm{CP}_{4}$ and $\mathrm{B}_{1}$ ODT batches was evaluated in $0.1 \mathrm{~N}$ $\mathrm{HCl}$ (Fig. 3). The dissolution profile of all three ODT batches revealed that $89 \%$ of ondansetron $\mathrm{HCl}$ was released within $5 \mathrm{~min}$. Further, a comparison of dissolution data of $\mathrm{CS}_{4}, \mathrm{CP}_{4}$ and $\mathrm{B}_{1}$ ODT batches was conducted using $\mathrm{f}_{1}$ and $\mathrm{f}_{2}$ statistics. Values of 1.9 and 1.852 were obtained for $\mathrm{CS}_{4} v s . \mathrm{B}_{1}$ and $\mathrm{CP}_{4} v s . \mathrm{B}_{1}$, respectively for $\mathrm{f}_{1}$. Also, a value of 67.4 for $\mathrm{CS}_{4} v s$. $\mathrm{B}_{1}$ and 67.82 for $\mathrm{CP}_{4}$ vs. $\mathrm{B}_{1}$ was obtained for $\mathrm{f}_{2}$. This indicated that the release profiles of $\mathrm{CS}_{4}, \mathrm{CP}_{4}$ and $\mathrm{B}_{1}$ ODT batches in $0.1 \mathrm{~N} \mathrm{HCl}$ were comparable and in good agreement with each other.

\section{CONCLUSION}

The present investigation revealed overwhelming influence of a concentration of glycine and chitosan in decreasing DT, WT and WAR. The statistical optimization design was useful in optimizing the composition of tablets containing glycine-chitosan mixture for the purpose of rapidly disintegrating the ODTs. The 
formulations containing chitosan $(5.5 \% \mathrm{w} / \mathrm{w})$ as disintegrant and glycine $(43.3 \% \mathrm{w} / \mathrm{w})$ as disintegration accelerator when compressed directly were found to produce ODTs of ondansetron $\mathrm{HCl}$ with $29 \pm 2 \mathrm{~s}$ DT. The evaluation of these ODTs revealed lower DT $30 \mathrm{~s}$ in comparison to $40 \mathrm{~s}$ shown by tablets containing croscarmellose sodium or crospovidone when compressed at the same $4.5 \mathrm{~kg}$ tablet crushing strength. Hence, chitosan: glycine combination can be suggested to function as an excellent disintegrating system for ODTs of ondansetrone $\mathrm{HCl}$.

Acknowledgements We gratefully acknowledge Panacea Biotec, Ltd. (Lalru, India), and Ind-Swift Labs, (Parwanoo, India) for providing gift samples of croscarmellose sodium, crospovidone and ondansetron $\mathrm{HCl}$, respectively, for this investigation.

\section{REFERENCES}

1) Salem I. I., Lopez J. M. R., Galan A. C., "Ondansetron Hydrochloride," ed. by Brittain H. G., Academic Press, California, 2001, pp. 301-308.

2) Dobetti L., Pharm. Technol. Drug Delivery Supplement, 44-50 (2001).

3) Ghosh T. K., Pfister W. R., "'Drug delivery to the oral cavity: Molecules to market." CRC Press., New York, 2005, pp. 337-356.

4) Corveleyn S., Remon J. P., Int. J. Pharm., 152, 215-225 (1997).

5) Koizumi K., Int. J. Pharm., 152, 127-131 (1997).

6) Gohel M., Patel M., Amin A., Agrawal R., Dave R., Bariya N., AAPS Pharm. Sci. Tech., 5, e36 (2004).
7) Verely P., Yarwood R., Manufac. Chem., 61, 36-37 (1990).

8) Sugimoto M., Narisawa S., Matsubara K., Yoshino H., Nakano M., Handa T., Chem. Pharm. Bull., 54, 175-180 (2006).

9) Bi Y., Sunada H., Yonezawa Y., Danjo K., Drug Dev. Ind. Pharm., 25, 571-581 (1999).

10) Zhao N., Augsburger L. L., AAPS Pharm. Sci. Tech., 6, E634-640 (2005).

11) Sutaryia V. B., Mashru R. C., Sankalia M. G., Sankalia J. M, ARS Pharm., 47, 293-311 (2006).

12) Fukami J., Yonemochi B., Yoshihashi Y., Terada K. S., Int. J. Pharm., 310, 101-109 (2006) .

13) Remunan-Lopez C., Bodmeier R., J. Contr. Rel., 44, 215-225 (1997).

14) Fukami J., Ozawa A., Yonemochi, B., Yoshihashi Y., Terada, K., Chem. Pharm. Bull., 53, 1536-1539 (2005).

15) Pharmacopoeia US-USP 30 NF 25, US Pharmacopoeial Convention, Rockville, MD, 2007.

16) Abdelbary G., Eouani C., Prinderre P., Joachim J., Reynier J., Piccerelle P., Int. J. Pharm., 292, 29-41 (2005).

17) Ritthidej G. C., Chomoto P., Pammangusa S., Drug Dev. Ind. Pharm., 20, 2109-2114 (1994).

18) Hoover J. E., "Remington-The Science and Practice of Pharmacy." 21st ed., Vol. II, New York, Lippincott Williams \& Wilkins, 2006, pp. 1311

19) Sakr A., Bose M., Menon A., Pharm. Ind., 55, 953-957 (1993). 